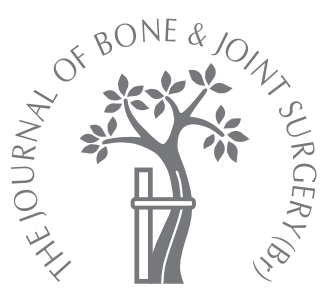

L. E. Ramseier,

T. I. Malinin,

H. T. Temple,

W. A. Mnaymneh,

G. U. Exner

From the University

of Zürich, Zürich, Switzerland

\title{
Allograft reconstruction for bone sarcoma of the tibia in the growing child
}

The outcome of tibial allograft reconstruction after resection of a tumour is inconsistent and has a high rate of failure. There are few reports on the use of tibial allografts in children with open growth plates. We performed 21 allograft reconstructions (16 osteoarticular, five intercalary) in 19 consecutive patients between seven and 17 years of age. Two had Ewing's sarcoma, one an adamantinoma and 16 osteosarcoma, one with multifocal disease.

Five patients have died; the other 14 were free from disease at the time of follow-up. Six surviving patients (eight allograft reconstructions) continue to have good or excellent function at a mean of 59 months (14 to 132). One patient has poor function at 31 months. The other seven patients have a good or excellent function after additional procedures including exchange of the allograft and resurfacing or revision to an endoprosthesis at a mean of 101 months (43 to 198). The additional operations were performed at a mean of 47 months (20 to 84) after the first reconstruction.

With the use of allograft reconstruction in growing children, joints and growth plates may be preserved, at least partially. Although our results remain inconsistent, tibial allograft reconstruction in selected patients may restore complete and durable function of the limb.

The tibia is a common site for osteosarcoma and Ewing's sarcoma, the most frequent malignant primary bone tumours in children; $27 \%$ of all osteosarcomas ${ }^{1}$ and $8 \%$ of Ewing's sarcoma ${ }^{2}$ arise at this site.

Although radiotherapy may achieve local control, complete resection gives better oncological results. ${ }^{2,3}$ If adequate resection margins are achieved after local excision of the tumour, limb reconstruction can be performed by endoprosthetic replacement, ${ }^{4}$ expandable endoprosthetic replacement ${ }^{5-7}$ or biological reconstructions such as shortening and rotationplasty, ${ }^{7,8}$ free microvascular bone transfer ${ }^{9}$ with or without allografts ${ }^{10-12}$ or allografts alone. ${ }^{13-21}$ Additionally, a technique for jointsparing resection using physeal distraction has been introduced by Canadell, Forriol and Cara, ${ }^{22}$ and San-Julian et al. ${ }^{23,24}$ With endoprosthetic reconstruction the knee joint is resected. Fixation of the prosthesis affects the growth plate of the distal femur even if the stem crossing the physis is smooth.

Limb-length discrepancy with the loss of the proximal tibial physis at a skeletal age of eight years can be expected to be about $4 \mathrm{~cm}$ at maturity, while the additional loss of the distal femoral physis gives a shortening of about $9 \mathrm{~cm}^{25}$
Allografts have long been an important method of segmental and articular bone reconstruction, ${ }^{26}$ allowing precise replacement. However, tibial allografts have shown inconsistent results and high rates of failure ${ }^{14-17}$ in studies mainly of adults. Few reports on tibial allografting concentrate on children with open growth plates. ${ }^{15,27-29}$ We believe that the results may be more favourable in children and describe our experience with this reconstruction technique.

\section{Patients and Methods}

We performed 21 allograft reconstructions (16 osteoarticular, five intercalary) in 19 consecutive patients with primary bone sarcomas of the tibia. Two had Ewing's sarcoma, one an adamantinoma and 16 had osteosarcoma. One patient with osteosarcomas involving both legs (distal and proximal tibial metaphysis, and the opposite tibial diaphysis) received three allografts. The age range at operation was between seven and 17 years, and the growth plates remained open to a varying extent in all patients. Examination included a structured interview, physical examination and radiological documentation using the ISOLS Allograft Radiographic evaluation protocol. ${ }^{30}$ The final results were graded according to the 
Table I. Clinical and radiological results in the 19 patients

\begin{tabular}{|c|c|c|c|c|c|c|c|c|c|c|c|}
\hline Case & $\begin{array}{l}\text { Age } \\
\text { (yrs) }\end{array}$ & Gender* & Diagnosis & $\begin{array}{l}\text { Local } \\
\text { complications }\end{array}$ & Management & $\begin{array}{l}\text { Time to } \\
\text { revision } \\
\text { (mths) }\end{array}$ & $\begin{array}{l}\text { Non-weight- } \\
\text { bearing } \\
\text { (mths) }\end{array}$ & $\begin{array}{l}\text { Leg-length } \\
\text { discrepancy } \\
\text { (cm) }\end{array}$ & $\begin{array}{l}\text { Fracture } \\
\text { union } \\
\text { (mths) }\end{array}$ & $\begin{array}{l}\text { Follow-up } \\
\text { (mths) }\end{array}$ & $\begin{array}{l}\text { Final } \\
\text { result }\end{array}$ \\
\hline 1 & 14 & $\mathrm{M}$ & $\begin{array}{l}\text { Osteosarcoma } \\
\text { right }^{\dagger}\end{array}$ & $\begin{array}{l}\text { Local wound } \\
\text { healing }\end{array}$ & $\begin{array}{l}\text { Soft-tissue } \\
\text { revision }\end{array}$ & $\begin{array}{l}\text { Post- } \\
\text { operative }\end{array}$ & 6 & 1.5 & 6 & 14 & Good \\
\hline 2 & 10 & $\mathrm{M}$ & $\begin{array}{l}\text { Osteosarcoma } \\
\text { right }^{\dagger}\end{array}$ & Infection & $\begin{array}{l}\text { Soft-tissue } \\
\text { revision }\end{array}$ & $\begin{array}{l}\text { Post- } \\
\text { operative }\end{array}$ & 0 & - & None & 17 & $\begin{array}{l}\text { Died from } \\
\text { disease }\end{array}$ \\
\hline 3 & 13 & $\mathrm{~F}$ & $\begin{array}{l}\text { Osteosarcoma } \\
\text { right }^{\dagger}\end{array}$ & $\begin{array}{l}\text { Allograft } \\
\text { fracture }\end{array}$ & $\begin{array}{l}\text { Converted to } \\
\text { alloprosthesis }\end{array}$ & 63 & 17 & 1 & 17 & 97 & Excellent \\
\hline 4 & 13 & $\mathrm{~F}$ & $\begin{array}{l}\text { Osteosarcoma } \\
\text { right }^{\dagger}\end{array}$ & $\begin{array}{l}\text { Local } \\
\text { recurrence }\end{array}$ & $\begin{array}{l}\text { Excision of } \\
\text { recurrence, } \\
\text { allograft } \\
\text { replacement }\end{array}$ & 30 & 9 & 0 & None & 30 & $\begin{array}{l}\text { Died from } \\
\text { disease }\end{array}$ \\
\hline 5 & 17 & $\mathrm{~F}$ & $\begin{array}{l}\text { Osteosarcoma } \\
\text { right }^{\dagger}\end{array}$ & Arthritis & None & - & 8 & - & 8 & 31 & Poor \\
\hline 6 & 17 & $\mathrm{~F}$ & $\begin{array}{l}\text { Osteosarcoma } \\
\text { left }^{\dagger}\end{array}$ & $\begin{array}{l}\text { Allograft } \\
\text { fracture }\end{array}$ & $\begin{array}{l}\text { Allograft } \\
\text { replacement }\end{array}$ & 20 & 15 & - & 15 & 198 & Good \\
\hline 7 & 14 & $\mathrm{~F}$ & $\begin{array}{l}\text { Osteosarcoma } \\
\text { left }^{\dagger}\end{array}$ & $\begin{array}{l}\text { Allograft } \\
\text { fracture }\end{array}$ & $\begin{array}{l}\text { Allograft } \\
\text { replacement }\end{array}$ & 55 & Brace & - & None & 65 & Good \\
\hline 8 & 13 & $\mathrm{M}$ & $\begin{array}{l}\text { Osteosarcoma } \\
\text { right }^{\dagger}\end{array}$ & $\begin{array}{l}\text { Local } \\
\text { recurrence }\end{array}$ & Amputation & 31 & 19 & - & 19 & 31 & $\begin{array}{l}\text { Died from } \\
\text { disease }\end{array}$ \\
\hline 9 & 16 & $\mathrm{M}$ & $\begin{array}{l}\text { Osteosarcoma } \\
\text { right }^{\dagger}\end{array}$ & None & - & - & 16 & 0 & 16 & 72 & $\begin{array}{l}\text { Died from } \\
\text { disease }\end{array}$ \\
\hline 10 & 13 & $\mathrm{~F}$ & $\begin{array}{l}\text { Osteosarcoma } \\
\text { right }^{\dagger}\end{array}$ & Arthritis & Alloprosthesis & 84 & 14 & 1 & 14 & 96 & Good \\
\hline 11 & 13 & $\mathrm{~F}$ & $\begin{array}{l}\text { Adamantinoma } \\
\text { right }^{\dagger}\end{array}$ & None & - & - & 5 & 0 & 5 & 81 & Excellent \\
\hline 12 & 12 & $\mathrm{~F}$ & $\begin{array}{l}\text { Osteosarcoma } \\
\text { left }^{\dagger}\end{array}$ & $\begin{array}{l}\text { Allograft } \\
\text { fracture }\end{array}$ & $\begin{array}{l}\text { Oncological } \\
\text { prosthesis }\end{array}$ & 20 & 21 & 2 & 21 & 43 & Good \\
\hline 13 & 13 & $\mathrm{~F}$ & $\begin{array}{l}\text { Osteosarcoma } \\
\text { right }^{\dagger}\end{array}$ & $\begin{array}{l}\text { Fracture/ } \\
\text { arthritis }\end{array}$ & $\begin{array}{l}\text { Allograft } \\
\text { replacement/ } \\
\text { resurfacing }\end{array}$ & $48 / 120$ & 2.5 & 2 & 16 & 150 & Excellent \\
\hline 14 & 9 & $\mathrm{M}$ & $\begin{array}{l}\text { Ewing's sarcoma } \\
\text { left }^{\dagger}\end{array}$ & $\begin{array}{l}\text { Allograft } \\
\text { fracture }\end{array}$ & Osteotomy & 96 & 2 & 2 & 24 & 132 & Excellent \\
\hline 15 & 10 & $\mathrm{~F}$ & $\begin{array}{l}\text { Osteosarcoma } \\
\text { left }^{\dagger}\end{array}$ & $\begin{array}{l}\text { Local wound } \\
\text { healing }\end{array}$ & $\begin{array}{l}\text { Soft-tissue } \\
\text { revision }\end{array}$ & $\begin{array}{l}\text { Post- } \\
\text { operative }\end{array}$ & 2 & 0 & 12 & 25 & $\begin{array}{l}\text { Died from } \\
\text { disease }\end{array}$ \\
\hline \multirow[t]{3}{*}{16} & 8 & $\mathrm{M}$ & $\begin{array}{l}\text { Osteosarcoma } \\
\text { dist tibia right }^{\dagger}\end{array}$ & None & - & - & 1.5 & - & 7 & 96 & Excellent \\
\hline & & & $\begin{array}{l}\text { Osteosarcoma } \\
\text { right }^{\ddagger}\end{array}$ & $\begin{array}{l}\text { Local wound } \\
\text { healing }\end{array}$ & $\begin{array}{l}\text { Soft-tissue } \\
\text { revision }\end{array}$ & $\begin{array}{l}\text { Post- } \\
\text { operative }\end{array}$ & 7 & - & None & 24 & Good \\
\hline & & & $\begin{array}{l}\text { Osteosarcoma } \\
\text { left }^{\ddagger}\end{array}$ & None & - & - & 4 & - & 7 & 24 & Excellent \\
\hline 17 & 7 & $\mathrm{M}$ & $\begin{array}{l}\text { Osteosarcoma } \\
\text { right }^{\ddagger}\end{array}$ & None & - & - & 1.5 & 2.5 & 7 & 73 & Excellent \\
\hline 18 & 12 & $\mathrm{~F}$ & $\begin{array}{l}\text { Ewing's sarcoma } \\
\text { right }^{\ddagger}\end{array}$ & Infection & $\begin{array}{l}\text { Removal and } \\
\text { shortening }\end{array}$ & 40 & 6 & - & None & 57 & Good \\
\hline 19 & 8 & $\mathrm{M}$ & $\begin{array}{l}\text { Osteosarcoma } \\
\text { left }^{\ddagger}\end{array}$ & $\begin{array}{l}\text { Local wound } \\
\text { healing }\end{array}$ & $\begin{array}{l}\text { Soft-tissue } \\
\text { revision }\end{array}$ & $\begin{array}{l}\text { Post- } \\
\text { operative }\end{array}$ & 1.5 & 1 & 19 & 31 & Excellent \\
\hline
\end{tabular}

* F, female; M, male

$\dagger$ osteoarticular allograft

‡ intercalary allograft for transepiphyseal resection

method of Mankin, Doppelt and Tomford. ${ }^{31}$ Peri-operative chemotherapy was based on the COSS 86/C, COSS 91, COSS 96, EICESS 92 and EURO Ewing 99 protocols.

In all cases the resected specimen had uncontaminated margins confirmed by histological examination.

All the allografts were fresh frozen, stored in liquid nitrogen gas phase and thawed immediately before implantation. They were radiologically matched to the recipient using a technique which had been previously described. ${ }^{32}$ Allografts from children with open physes were excluded as being unsuitable for transplantation since fractures have been seen to occur at the physes. All proximal tibial allografts were covered by a local proximally pedicled medial gastrocnemius flap for soft-tissue cover and restoration of the extensor apparatus.
Full weight-bearing was allowed when fusion between the allograft and host bone was radiologically confirmed.

The allograft replacement was longer in several patients than the resected part of the tibia when the soft-tissue situation allowed for this to minimise anticipated limb-length discrepancy.

\section{Results}

The mean follow-up was for 66 months (14 to 198). All surviving patients were satisfied with the results regarding their body image, the retained limb and overall function (Table I). Five patients died from their disease, one of whom required amputation because of local recurrence. Six surviving patients (eight allograft reconstructions) continued to have a good or excellent function of their primary recon- 


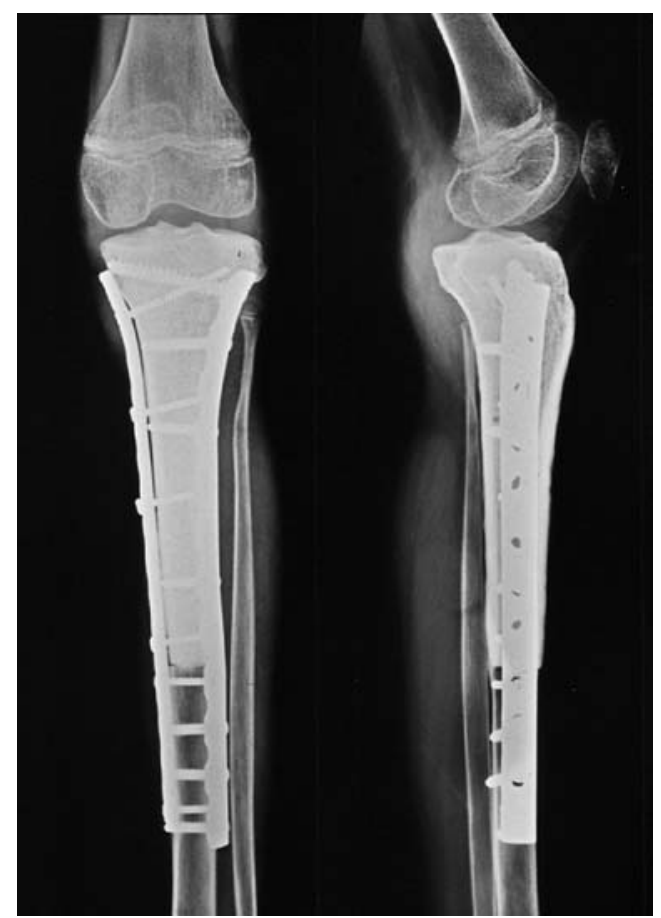

Fig. 1a

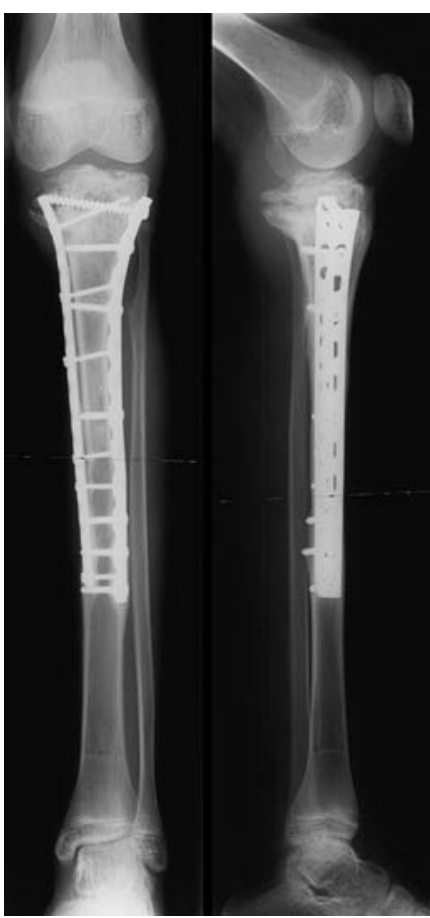

Fig. $1 b$

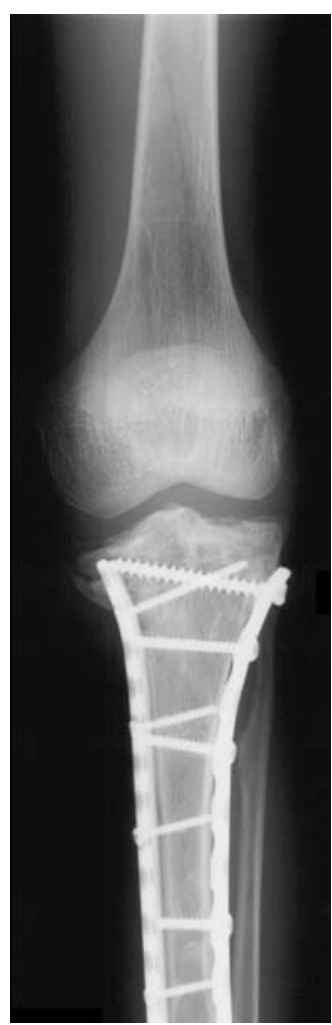

Fig. 1c

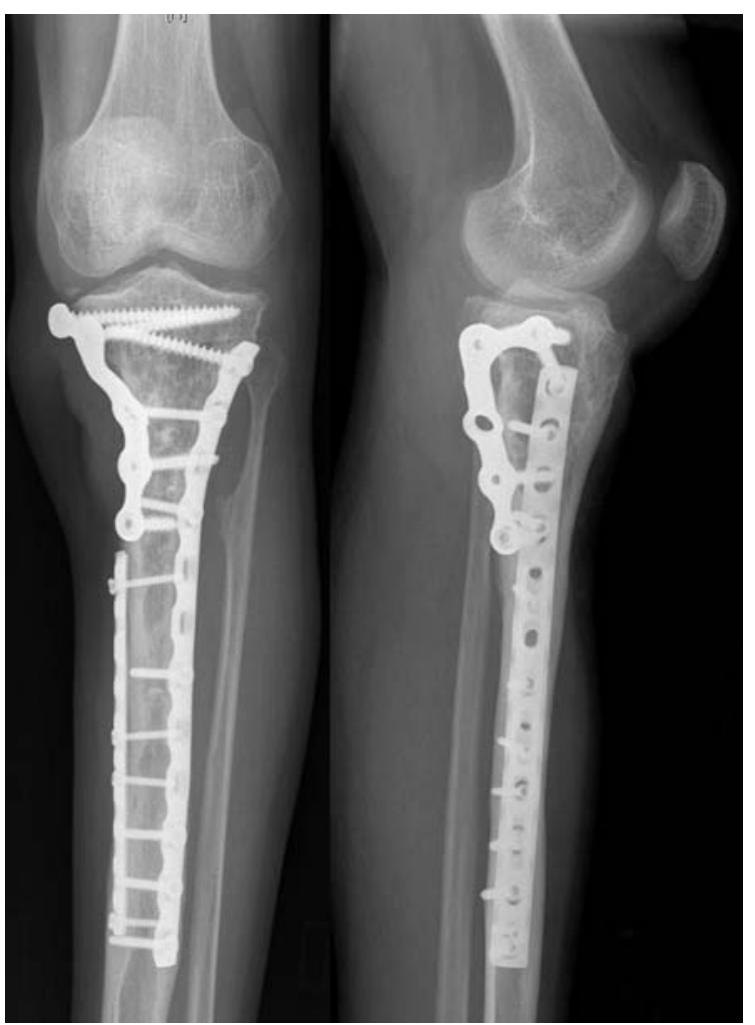

Fig. 1d

Radiographs of a proximal tibial osteoarticular allograft in a patient with Ewing's sarcoma showing a) the reconstruction at seven months after surgery, b) at 42 months after the primary reconstruction osteolysis of the medial tibial plateau and infraction, c) eight months later with bracing and protected weight-bearing modelling of the medial tibial plateau and continuing healing of the fracture and d) five years after valgus osteotomy with interposition of an autologous iliac-crest bone block, with healing, correct alignment and retained joint spaces. 
struction at a mean of 59 months (14 to 132). One had poor function after 31 months due to arthritis. The remaining seven surviving patients required additional operations at a mean of 47 months (20 to 84 ) after the primary procedure. The revision operations included exchange of allografts, autografting with corrective osteotomy, resurfacing of the allograft with an endoprosthesis or replacement of the allograft with a reconstruction prosthesis. After these supplementary operations good or excellent function was achieved at a mean of 101 months (43 to 198) after the revision procedure. Even in these patients, in whom no revision surgery was required to the allograft, there was a high incidence of local problems with wound healing for which additional operative treatment was needed. The ten-year result of a patient with an Ewing sarcoma is shown in Figure 1.

Leg-length discrepancy developed in most patients as a result of loss of the physis. The extent of the inequality depended on the age at first treatment in accordance with the findings of Anderson et al..$^{25}$ The adjacent distal femoral physis continued to grow normally and maintain congruence with the transplant. At the end of skeletal growth, any small mismatch between the retained normal femoral epiphysis and the tibial osteocartilaginous allograft was asymptomatic provided that the allograft did not develop degenerative changes. We found that in transepiphyseal resection the retained epiphysis maintained the potential to grow in width and degenerative joint changes did not occur. However, osteoarticular allografts produced variable results from no degenerative change to advanced arthritis requiring resurfacing arthroplasty (Table I).

The mean time to radiological union at the graft-host junction was 10.5 months (5 to 24). Two patients died at 17 and 30 months, respectively, before visible fusion.

\section{Discussion}

Transepiphyseal resection and allograft replacement gave excellent results as expected with retention of the knee. Only a few similar cases have been reported in the literature ${ }^{20,22}$ making comparison with endoprosthetic reconstructions difficult. Intercalary allografts appear to have better results than osteoarticular allografts. ${ }^{16}$ In our series there was no obvious difference between the five osteoarticular and the 16 intercalary allografts in any of the parameters studied. An advantage over endoprosthetic reconstruction is the preservation of the physis of the distal femur, accounting for about $33 \%$ of the total limb growth. Limb-length discrepancy greater than $2.5 \mathrm{~cm}$ occurred only rarely and was managed by shortening of the contralateral limb except in one patient for whom limb lengthening is proposed.

In the literature the high rate of complications after tibial allograft reconstruction has resulted in their limited use. High rates of infection, fractures and arthritis have been reported. ${ }^{13,14,17,32,33}$ Rödl et $\mathrm{al}^{13}$ in a series of seven patients, found that in five of the six who survived the allograft required revision to an endoprosthetic replacement. Allograft reconstruction in the growing child is controversial. Rödl et $\mathrm{al}^{13}$ considered this treatment to be at best a temporary solution. By contrast, Alman et $\mathrm{al}^{27}$ found allograft reconstruction to be useful in skeletally immature individuals, but observed more frequent complications in children as compared with adults. Cara and Canadell ${ }^{15}$ reported that patients undergoing alloprosthetic composites had fewer complications and better functional results than those with osteoarticular allograft reconstruction. The results in the literature dealing specifically with children with an open physis appear to be more encouraging. Manfrini et $\mathrm{a}^{10}$ reported good results in nine of ten surviving patients who had tibial allograft reconstruction.

In our study, seven allografts in 14 disease-free patients failed partially or completely at longer follow-up, but salvage was possible. The patients received a second allograft and/or a subsequent resurfacing procedure. Preservation of bone stock was an important factor in allowing subsequent revision surgery. In our series amputation was performed in only one patient. When revising the salvaged limb because of allograft fracture additional bone could be added to correct limb-length inequality.

One failure was probably attributable to post-operative local radiotherapy with damage to the host bone and soft tissue. Six patients retained eight allografts (four osteoarticular, four intercalary) at follow-up at one to 11 years, which functioned well and allowed full weight-bearing. Our results are similar to those of Manfrini et al. ${ }^{10}$

However, osteointegration is unpredictable and the use of added microvascular bone transfer may be a useful adjunct to improve allograft host integration. ${ }^{10}$ The outcome of tibial allograft reconstruction remains uncertain with results ranging from excellent with full incorporation and osseointegration of the allograft and long-lasting joint function to failure with accelerated and advanced arthritis, fractures, nonunion and infection. ${ }^{32}$

In children, the potential to perform transarticular resection with preservation of the proximal growth plates for further growth, or to spare the joint surface by replacing an intercalary segment after transepiphyseal or transphyseal resection when appropriate, make allografting an appealing option in the management of this unpleasant disease. However, a high rate of failure requiring additional surgery has to be accepted and complications are common even with a successful outcome.

No benefits in any form have been received or will be received from a commercial party related directly or indirectly to the subject of this article.

\section{References}

1. Bielack S, Kempf-Bielack B, Schwenzer D, et al. Neoadjuvant therapy for localized osteosarcoma of extremities: results from the Cooperative osteosarcoma study group COSS of 925 patients. Klin Padiatr 1999;211:260-70 (in German).

2. Paulussen M, Ahrens S, Dunst J, et al. Localized Ewing tumor of bone: final results of the cooperative Ewing's Sarcoma Study CESS 86. J Clin Oncol 2001;19: 1818-29.

3. Hermanek P, Wittekind C. The pathologist and the residual tumor (R) classification. Pathol Res Pract 1994;190:115-23. 
4. Ham SJ, Schraffordt Koops H, Veth RP, et al. Limb salvage surgery for prime bone sarcoma of the lower extremities: long-term consequences of endoprosthetic reconstructions. Ann Surg Oncol 1998;5:423-36.

5. Unwin PS, Walker PS. Extendible endoprostheses for the skeletally immature. Clin Orthop 1996;322:179-93.

6. Neel MD, Wilkins RM, Rao BN, Kelly CM. Early multicenter experienced with a noninvasive expandable prosthesis. Clin Orthop 2003;415:72-81.

7. Hillmann A, Hoffmann C, Gosheger G, Krakau H, Winkelmann W. Malignan tumor of the distal part of the femur or the proximal part of the tibia: endoprosthetic replacement or rotationplasty: functional outcome and quality-of-life measurements. J Bone Joint Surg [Am] 1999;81-A:462-8.

8. Hardes J, Gebert C, Hillmann A, Winkelmann W, Gosheger G. Rotationplasty in the surgical treatment plan of primary malignant bone tumors: possibilities and limits. Orthopade 2003;32:965-70 (in German).

9. Hsu RW, Wood MB, Sim FH, Chao EY. Free vascularised fibular grafting for reconstruction after tumour resection. J Bone Joint Surg [Br] 1997;79-B:36-42.

10. Manfrini M, Gasbarrini A, Malaguti C, et al. Intraepiphyseal resection of the proximal tibia and its impact on lower limb growth. Clin Orthop 1999;358:111-19.

11. Hennen J, Sabo D, Martini AK, Bernd L. Mantel transplant for defect reconstruction after resection of malignant bone tumors of the lower extremity. Unfallchirurg 2002;105:120-7 (in German).

12. Ozaki T, Hillmann A, Wuisman P, Winkelmann W. Reconstruction of tibia by ipsilateral vascularized fibula and allograft: 12 cases with malignant bone tumors. Acta Orthop Scand 1997;68:298-301.

13. RödI RW, Ozaki T, Hoffmann C, et al. Osteoarticular allograft in surgery for highgrade malignant tumours of bone. J Bone Joint Surg [Br] 2000;82-B:1006-10.

14. Hornicek FJ Jr, Mnaymneh W, Lackman RD, Exner GU, Malinin TI. Limb salvage with osteoarticular allografts after resection of proximal tibia bone tumors. Clin Orthop 1998;352:179-86

15. Cara JA, Canadell J. Limb salvage for malignant bone tumors in young children. J Pediatr Orthop 1994;14:112-18.

16. Dick HM, Malinin TI, Mnaymneh WA. Massive allograft implantation following radical resection of high-grade tumors requiring adjuvant chemotherapy treatment Clin Orthop 1985;197:88-95.

17. Brien EW, Terek RM, Healey JH, Lane JM. Allograft reconstruction after proximal tibial resection for bone tumors: an analysis of function and outcome comparing allograft and prosthetic reconstructions. Clin Orthop 1994;303:116-27.

18. Gebbhardt MC, Flugstad DI, Springfield DS, Mankin HJ. The use of bone allografts for limb salvage in high-grade extremity osteosarcoma. Clin Orthop 1991;270:181-96.
19. Exner GU, Hauser R. Reconstruction of large segmental defects of the lower extremities following resection of malignant and locally aggressive bone tumors. Schweiz Rundsch Med Prax 1991;44:1214-24 (in German).

20. Muscolo DL, Ayerza MA, Aponte-Tinao L, Ranalletta M, Abalo E. Intercalary femur and tibia segmental allografts provide an acceptable alternative in reconstructing tumor resections. Clin Orthop 2004;426:97-102.

21. Musculo DL, Ayerza MA, Aponte-Tinao LA, Ranalletta M. Partial epiphysea preservation and intercalary allograft reconstruction in high-grade metaphyseal osteosarcoma of the knee. J Bone Joint Surg [Am] 2004;86-A:2686-93.

22. Canadell J, Forriol F, Cara JA. Removal of metaphyseal bone tumours with preservation of the epiphysis: physeal distraction before excision. J Bone Joint Surg $[\mathrm{Br}]$ 1994;76-B:127-32

23. San-Julian M, Aquerreta JD, Benito A, Canadell J. Indications for epiphyseal preservation in metaphyseal malignant bone tumors of children: relationship between image methods and histological findings. J Pediatr Orthop 1999;19:543-8.

24. San-Julian M, Dolz R, Garcia-Barrecheguren E, et al. Limb salvage in bone sarcomas in patients younger than age 10: a 20-year experience. J Pediatr Orthop 2003; 23:753-62.

25. Anderson M, Green WT, Messner MB. Growth and predictions of growth in the lower extremities. Am J Orthop 1963;45:1-14.

26. Lexer E. Die freien Transplantationer. Stuttgart: Verlag von Ferdinand Enke, 1924.

27. Alman BA, De Bari A, Krajbich JI. Massive allografts in the treatment of osteosarcoma and Ewing sarcoma in children and adolescents. J Bone Joint Surg $[A m]$ 1995;77-A:54-64.

28. Kohler R, Lorge F, Brunat-Mentigny M, Noyer D, Patricot L. Massive bone allografts in children. Int Orthop 1990;14:249-53.

29. Kumta SM, Leung PC, Griffith JF, et al. A technique for enhancing union of allograft to host bone. J Bone Joint Surg [Br] 1998;80-B:994-8.

30. Glasser $\mathbf{D}$, Langlais $\mathbf{F}$. The ISOLS radiological implant evaluation system. In: Langlais F, Tomeno B, eds. Limb salvage: major reconstructions in oncologic and nontumoral conditions. Heidelberg: Springer, 1991.

31. Mankin HJ, Doppelt S, Tomford W. Clinical experience with allograft implantation: the first ten years. Clin Orthop 1983;174:69-86.

32. Mnaymneh W, Malinin TI, Makley JT, Dick HM. Massive osteoarticular allografts in the reconstruction of extremities following resection of tumors not requiring chemotherapy and radiation. Clin Orthop 1985;197:76-87.

33. Clohisy DR, Mankin HJ. Osteoarticular allografts for reconstruction after resection of a musculoskeletal tumor in the proximal end of the tibia. J Bone Joint Surg [Am] 1994;76-A:549-54 